\title{
EFFICIENCY VERSUS VALUE OF JOINT-STOCK COMPANIES FROM AGRIBUSINESS SECTOR OF THE WARSAW STOCK EXCHANGE - A PERSPECTIVE TOWARDS TRADE-OFF DECISIONS
}

\author{
Serhiy Zabolotnyy ${ }^{1}, \mathrm{PhD}$, assistant professor; \\ Miroslaw Wasilewski ${ }^{2}$, dr hab., associate professor \\ 1,Warsaw University of Life Sciences - SGGW, Department of Finance, \\ ${ }^{2}$ Warsaw University of Life Sciences - SGGW, Department of Finance
}

\begin{abstract}
The article presents relations between the enterprise value, efficiency and capital structure of Polish joint-stock companies from agribusiness sector listed on the Warsaw Stock Exchange. The enterprise value of companies from WIG-FOOD sector was primarily subject to the market capitalization and debt fluctuations. A simultaneous decrease of the debt level and rise in cash resulted in a higher market capitalization due to a fading bankruptcy risk. A growth of earnings and profitability ratios had a positive impact on the market capitalization and enterprise value that was in line with theoretical assumption of value maximization principle. Considering the influence of profitability and debt level on the market capitalization it could be expected that managers would strive for reducing external sources of financing and increasing operating efficiency to maximize the value of their companies for shareholders.
\end{abstract}

Key words: enterprise value, market capitalization, the Warsaw Stock Exchange, WIG-FOOD index, agribusiness.

JEL code: G30, G32, G33

\section{Introduction}

Valuation of a company is one of the most difficult tasks for financial managers. In financial literature, value of an asset is defined as a function of a cash flow generated by that asset, the life of the asset, the expected growth in the cash flows and the riskiness associated with the cash flows (Damodaran A., 1999, Higgins R., 2012). In other words, the firm's value depends on its operating efficiency, market potential and specific risk associated with its business. The riskiness of a company is commonly characterized by the firm's weighted average cost of capital and is reflected in a discount rate for its cash flow (Berk J., DeMarzo P., 2017). Thus, according to a traditional approach of the DCF model, the company with high operating efficiency and growth rate of earnings with minimum level of risk will generate the maximum value for investors (Panfil M., 2009). Regarding to this, there is a direct relation between the efficiency and value of the company: higher expected earnings and profitability ratios will lead to a growth of market capitalization and enterprise value. However, the impact of risk and cost of capital on the value of business is not so obvious. Trade-off theory of capital structure states that a company can have debt levels that balance the tax advantages of additional debt against the costs of possible financial distress (Myers S., 2001). At the same time there is a view that under some assumptions the capital structure of a company does not influence its value (Modigliani F., Miller M., 1958). Practically, availability of tax benefits due to leverage as well as asymmetry of information justify the significance of capital structure decisions for business valuations.

The problem of capital structure and its influence on the value of a firm is particularly important in agriculture and food industry as these sectors are subject to a number of specific external risk factors related to seasonality, force majeure or fluctuations of supply and demand (Kahan D., 2008, Franc-Dabrowska J., Madra-Sawicka M., Bereznicka J., 2017). Besides risk aversion of managers of agricultural companies gives an additional argument for a pecking-order theory (Frank M., Goyal V., 2003). At the same time, profitability remains a key indicator for operating efficiency of agricultural companies and has a great impact on their value. 
The aim of the research is to define relations between the enterprise value, efficiency and capital structure of Polish joint-stock companies from the Warsaw Stock Exchange. Poland is an important global producer and exporter of agricultural and food products and agribusiness traditionally forms one of essential segments for investing in its economy by local and international entities. Hence understanding the principles of value creation and its main determinants in agricultural companies can give an additional impetus both for managers and investors who are engaged in Polish market.

An enterprise value of the company has been calculated according to the following formula:

Enterprise Value $=$ Market Capitalization $\boldsymbol{-}$ Cash and Equivalents + Preferred Equity + Minority Interest + Total Debt

Main factors influencing the enterprise value are the market value of its equity and debt as well as non-operating cash and its equivalents. It should be mentioned that the market capitalization is highly dependent on future cash flow expectations, while the amount of debt arises from the financing strategy of business and largely determines the weighted average cost of capital. Nonoperating cash reduces the firm's value because commonly it does not aid in generation of future cash flows and can be used for debt repayment. Taking into consideration these components of the enterprise value different profitability and debt ratios were used to characterize the efficiency of business and its capital structure (table 1 ).

\section{Ratios of financial efficiency and capital structure}

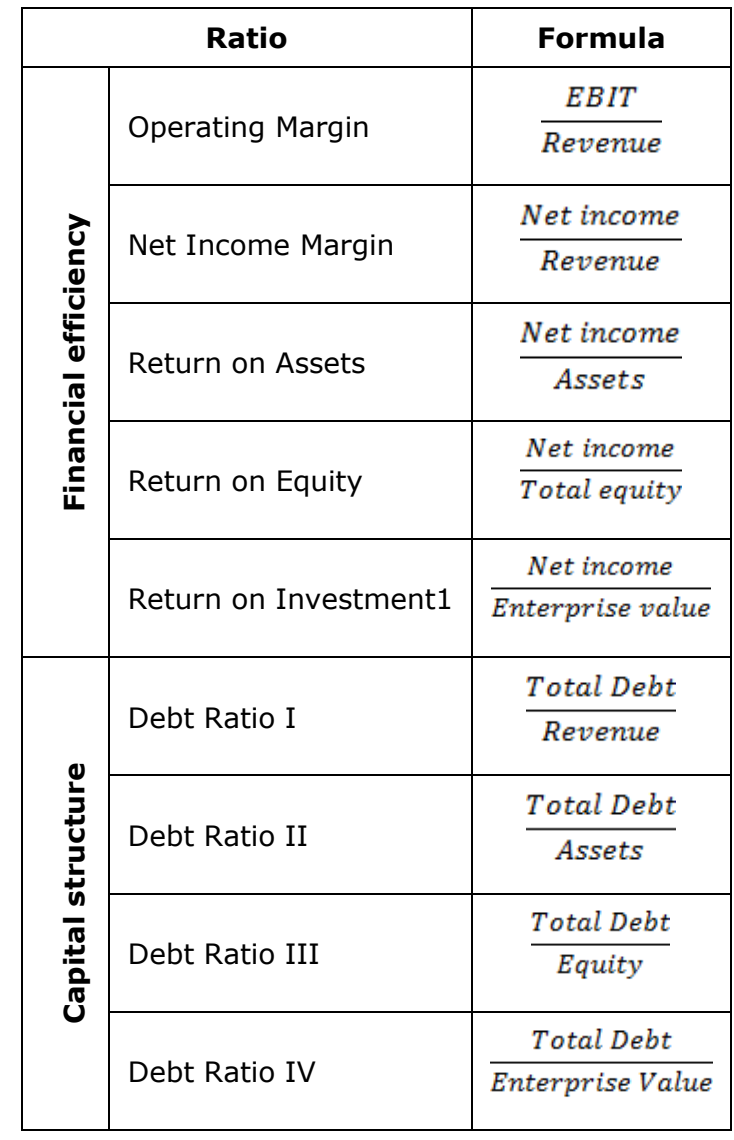

Source: authors' research

In the next step of the research, Pearson correlation coefficients were used to depict statistically significant relations between the market capitalization, enterprise value, profitability and capital

${ }^{1}$ In spite of various definitions of the return on investment, authors use the proposed construction as one of the measures of the efficiency of investing in particular company. 
structure ratios (Stanisz A., 2007). Basing on financial and statistical analysis recommendations concerning value creation for shareholders' have been formulated. Primary empirical data were extracted from financial statements of joint-stock companies from the food sector of the Warsaw Stock Exchange. The ultimate sample included 24 companies. Other financial data for the research was collected from the Warsaw Stock Exchange, EMIS and Bloomberg financial databases and related to period of 2011-2015.

\section{Research results and discussion}

After the accession to the European Union Poland has benefited from a very fast catch up process. For example, in 2015, Poland's GDP per capita expressed in purchasing power standards reached 69 \% of the EU average, up from 53 \% in 2007 (European Commission, 2017). In 20112015, the nominal GDP of Poland has been constantly increasing from $1566.8 \mathrm{mln}$ PLN to $1799.4 \mathrm{mln}$ PLN that gave the compound annual growth rate of $3.52 \%$ (Figure 1). This illustrated a rapid development of Polish economy propelled by such fundamental factors as expanding financial sector, increasing business climate and growing consumer demand. Besides a sharp upward tendency has been noticed in agricultural sector as agricultural income in 2004-2011 has increased by 95.2 \% (Ministry of Agriculture and Rural Development, 2015).

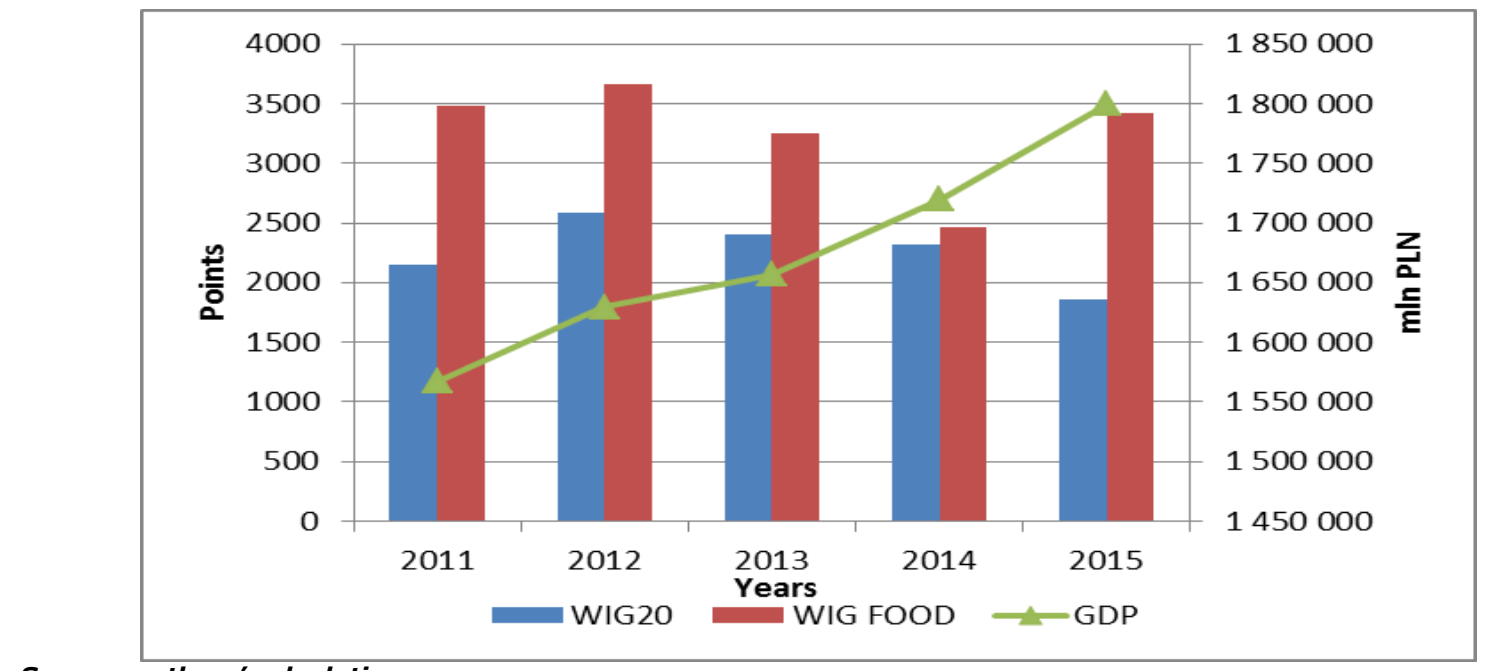

Source: authors' calculations

Fig.1 Gross domestic product of Poland versus WIG20 and WIG-FOOD indices

Polish capital market has benefited from the overall economic growth to a lesser extent. The compound annual growth rate of WIG20 index including Polish listed companies with the highest capitalization came to $(-3.51 \%)$ while WIG-FOOD index of firms from agribusiness sector decreased by $0.44 \%$ annually. This could be largely explained by peculiarities of Polish capital market determined by low liquidity and great exposure to global volatility of cash flows in emerging markets. Other specific factors also included a low level of diversification of companies within Polish capital indices. On one hand, a large part of WIG20 index was represented by state-owned commodity sector companies influenced by commodity price fluctuations and political climate. On the another hand, financial institutions being a substantial group of companies in WiG20 index suffered from decreasing interest rates and margins, consolidation processes within the sector as well as from tightening competition. At the same time WIG-FOOD index was characterized by increased volatility in 2011-2015. The drop of an index from 3666 in 2012 to 3249 points in 2013 was related to a weakening demand on the products of food industry in Poland (Bartkiewicz P., 
Lecki M., 2015). Additionally, a slump of an index by $24 \%$ in 2014 was provoked by a group of listed companies operating in Ukrainian market. At that time a political and military conflict in Ukraine resulted in substantial losses in these firms and led to a rapid decrease in their market capitalization. A global relief of investors related to the conflict in Ukraine as well as improving demand for food products has pushed the capitalization of the whole index by $38.6 \%$ to 3420 points in 2015. Financial situation of the companies from WIG-FOOD Index extensively corresponded to their market capitalization (figure 2). In 2011-2013 food companies demonstrated a stable market expansion supported by the growth of their balance sheets. During this period aggregated firms' revenue rose by $19.2 \%$ while assets and equity increased by $20.1 \%$ and $50.2 \%$ respectively. Net income added $36.8 \%$ in 2013 comparing to 2011. Due to substantial unrealized $^{1}$ and net losses of Ukrainian entities, the aggregate equity capital of food companies decreased by $24.4 \%$ and assets fell by $18.9 \%$ in 2014. Apart of a rapid growth in the capitalization in 2015 the level of equity capital rose moderately by $5.28 \%$ and revenue grew only by $0.66 \%$ in relation to 2014 . This period also led to a drop in assets value by $2.8 \%$. Generally the compound annual growth rate of revenue for the whole WIG-FOOD index was $2.2 \%$ while net income decreased by $13.4 \%$ annually. The same ratio for total assets and equity amounted to $(-1.4 \%)$ and $4.6 \%$ accordingly.

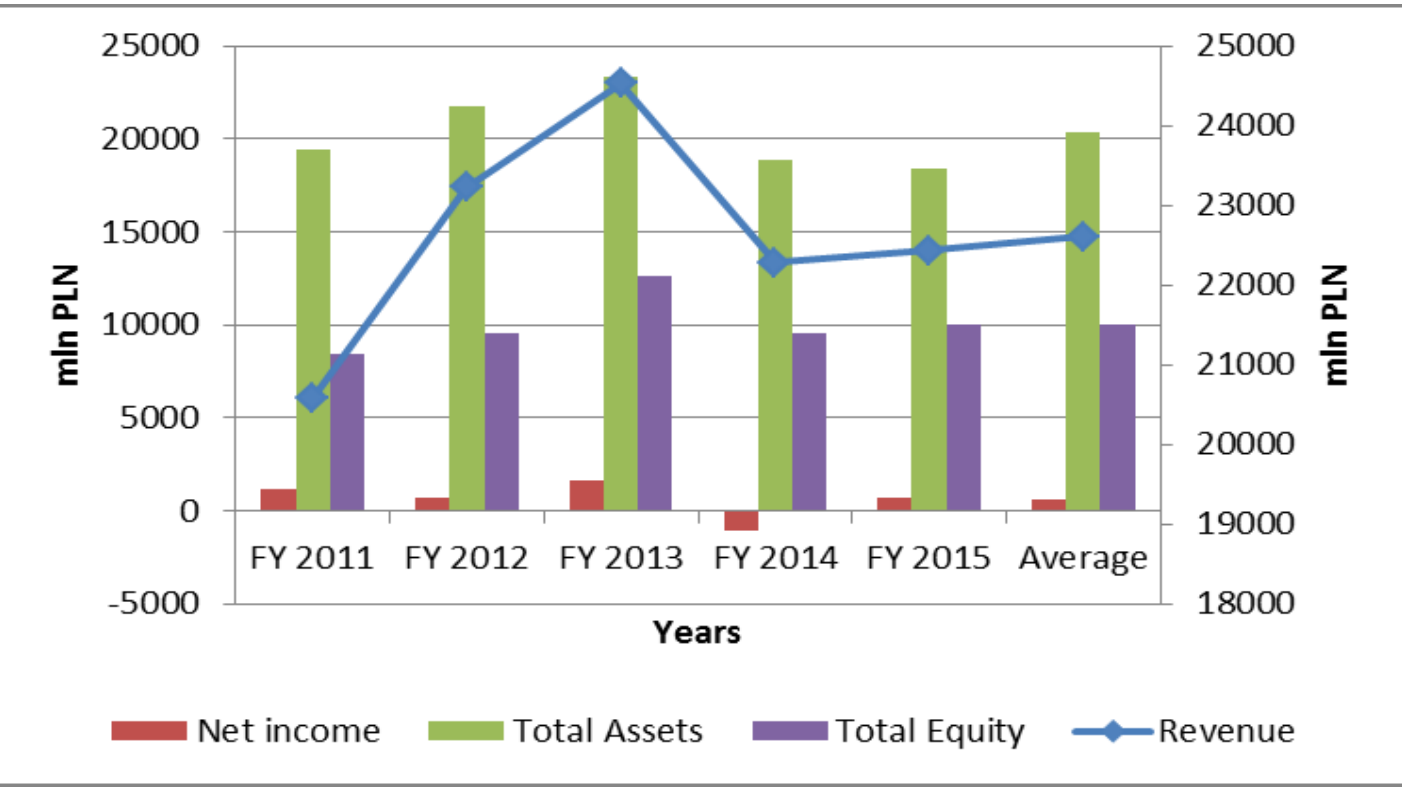

Source: authors' calculations

Fig. 2. Financial situation of companies from WIG FOOD Index

In 2011-2015, the total enterprise value of companies from WIG-FOOD index has decreased from $18701.2 \mathrm{mln}$ PLN to $15202.9 \mathrm{mln}$ PLN in 2015 and the compound annual growth rate came to $(-5 \%)$ (figure 3$)$. The average enterprise value in the related period was $17366.9 \mathrm{mln}$ PLN of which $68.4 \%$ accounted for market capitalization and the rest was mainly formed by debt $36.5 \%$. At the same time cash and cash equivalents that reduced enterprise value reached $6.4 \%$ on average. Companies from WIG-FOOD index has maintained their cash balance from $1068.6 \mathrm{mln}$ PLN in 2011 to $1734.3 \mathrm{mln}$ PLN in 2015 with compound annual growth rate coming to $12.9 \%$. 


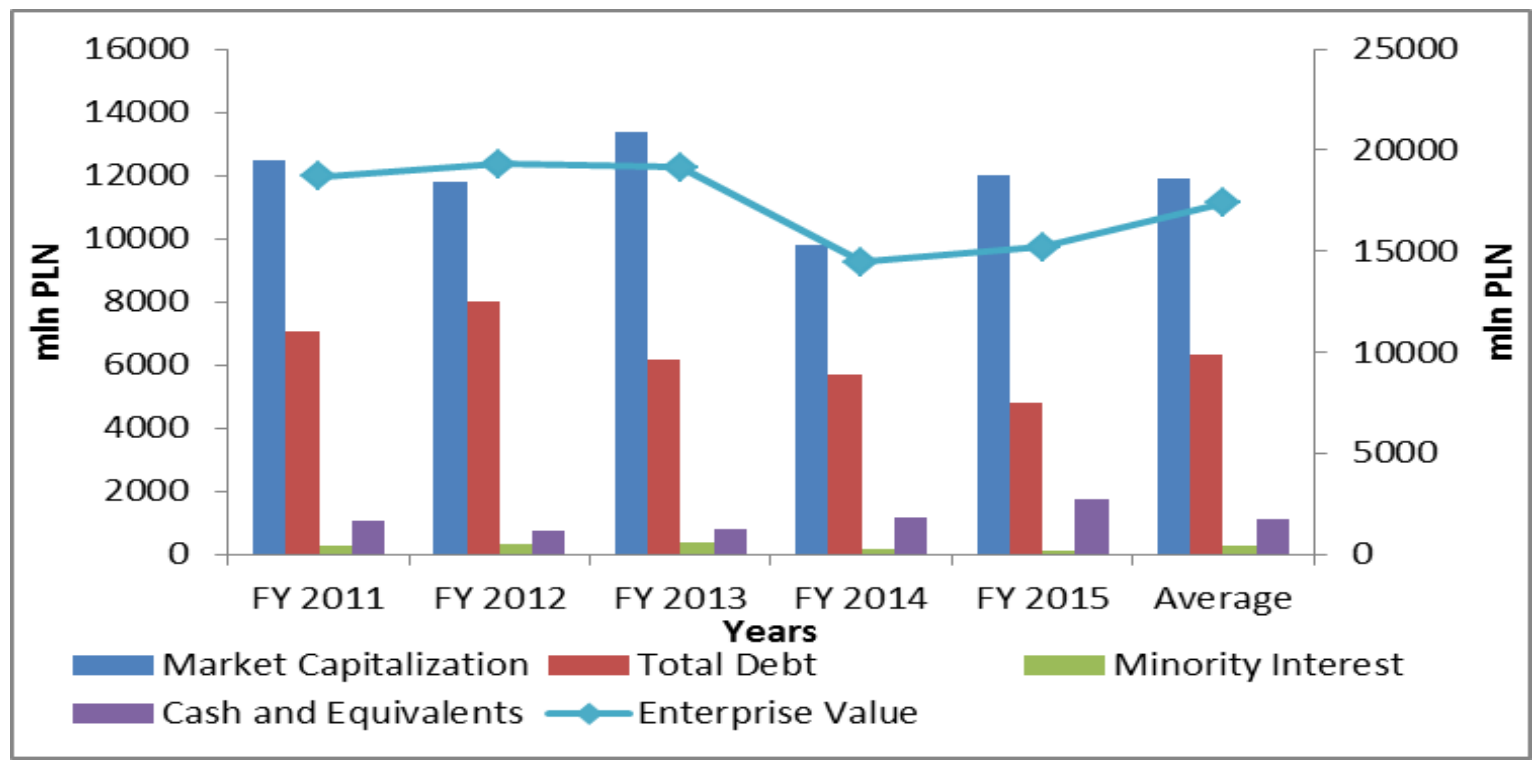

Source: authors' calculations

Fig. 3. The decomposition of enterprise value of companies from WIG FOOD Index

It should be mentioned that the total debt of companies from WIG-FOOD index fell by $31.9 \%$, while market capitalization decreased only by $3.6 \%$ in 2011 comparing to 2015. In other words, a substantial drop of debt share in enterprise value gave a clear signal of the fading financial risk of WIG-FOOD companies and this shielded market prices from sharp declines. Moreover, the decrease of debt level by $22.6 \%$ in 2013 and by $15.7 \%$ in 2015 in relation to a previous year gave a rise of market capitalization by $13.8 \%$ and $22.7 \%$ accordingly. A strong evidence of the impact of financing decisions on value of a company has been received: investors positively interpreted the fall of debt levels of companies from WIG-FOOD Index.

Multiples of companies from WIG-FOOD index gradually went down in 2011-2015 that reflected the drop in stock prices and could be perceived as a buying opportunity (Table 2).

Table 2

Relations between the enterprise value, market capitalization and efficiency of companies from WIGO-FOOD index

\begin{tabular}{|c|c|c|c|c|c|c|}
\hline \multirow{2}{*}{ Period } & \multicolumn{7}{|c|}{ Ratio } \\
\cline { 2 - 7 } & MC1/Sales & MC/EBIT & $\begin{array}{c}\text { MC/Net } \\
\text { income }\end{array}$ & EV /Sales & EV/EBIT & $\begin{array}{c}\text { EV/Net } \\
\text { income }\end{array}$ \\
\hline FY 2011 & 0.61 & 6.78 & 10.4 & 0.91 & 10.2 & 15.6 \\
\hline FY 2012 & 0.51 & 7.14 & 16.7 & 0.83 & 11.7 & 27.4 \\
\hline FY 2013 & 0.55 & 8.68 & 8.2 & 0.78 & 12.4 & 11.7 \\
\hline FY 2014 & 0.44 & 5.87 & -9.0 & 0.65 & 8.7 & -13.3 \\
\hline FY 2015 & 0.54 & 4.81 & 17.8 & 0.68 & 6.1 & 22.5 \\
\hline $\begin{array}{c}\text { Weighted } \\
\text { average }\end{array}$ & $\mathbf{0 . 5 3}$ & $\mathbf{6 . 4 6}$ & $\mathbf{1 9 . 0}$ & $\mathbf{0 . 7 7}$ & $\mathbf{9 . 4}$ & $\mathbf{2 7 . 7}$ \\
\hline
\end{tabular}

Source: authors' calculations

The price to sales ratio decreased from 0.61 to 0.54 and the price to operating income ratio fell from 6.78 to 4.81 . In other words, the growth in market capitalization of companies was slower than an increase of their sales and operating profit. The price to earnings ratio demonstrated the highest volatility falling from 10.4 in 2011 to (-9.0) in 2014 and then rising again to 17.8 in 2015.

\footnotetext{
${ }^{1}$ Market capitalization. A commonly used way to calculate market multiples is to divide price 'per share' by the value 'per share' (Berk J., DeMarzo P., 2017). The authors use aggregate values to calculate multiples and common ratio names to identify them. 
Such a situation emanated from a huge disproportion between market capitalization and net income of companies. A slide in enterprise value to sales ratio from 0.91 to 0.68 or by $25.4 \%$ comparing to a moderate drop in price to sales ratio by $11.5 \%$ in 2011 related to 2015 was a consequence of a significant decrease in the amount of debt of companies from WIG-FOOD index. At the same period of time the enterprise value to operating income ratio slumped from 10.2 to 6.1 .

Companies from WIG FOOD index were characterized by a relatively high volatility of margins and returns in 2011-2015 (Table 3).

Financial efficiency of companies from WIG-FOOD index

Table 3

\begin{tabular}{|c|c|c|c|c|c|}
\hline \multirow{2}{*}{ Period } & \multicolumn{5}{|c|}{ Ratio ( \%) } \\
\cline { 2 - 6 } & $\begin{array}{c}\text { Operating } \\
\text { Margin }\end{array}$ & $\begin{array}{c}\text { Net income } \\
\text { margin }\end{array}$ & $\begin{array}{c}\text { Return on } \\
\text { Assets }\end{array}$ & $\begin{array}{c}\text { Return on } \\
\text { Equity }\end{array}$ & $\begin{array}{c}\text { Net } \\
\text { income/EV }\end{array}$ \\
\hline FY 2011 & 8.9 & 5.8 & 6.2 & 14.3 & 6.4 \\
\hline FY 2012 & 7.1 & 3.0 & 3.3 & 7.4 & 3.7 \\
\hline FY 2013 & 6.3 & 6.7 & 7.0 & 13.0 & 8.6 \\
\hline FY 2014 & 7.5 & -4.9 & -5.7 & -11.3 & -7.5 \\
\hline FY 2015 & 11.1 & 3.0 & 3.7 & 6.7 & 4.4 \\
\hline $\begin{array}{l}\text { Weighted } \\
\text { average }\end{array}$ & $\mathbf{8 . 1}$ & $\mathbf{2 . 8}$ & $\mathbf{3 . 1}$ & $\mathbf{6 . 2}$ & $\mathbf{3 . 6}$ \\
\hline
\end{tabular}

Managers kept an upward trend of operating margins that rose from $8.9 \%$ in 2011 to $11.1 \%$ in 2015. Nevertheless, net income fluctuations resulted in decreasing efficiency ratios of food companies. In the relevant period, net income margin fell from $5.8 \%$ to $3.0 \%$ while both return on assets and equity slumped from $6.2 \%$ to $3.7 \%$ and from $14.3 \%$ to $6.7 \%$ accordingly. Negative profitability ratios in 2014 were caused by mentioned losses of Ukrainian companies from WIG-FOOD index. Generally, in 2011-2015 an average operating margin came to $8.1 \%$ and net income margin reached $2.8 \%$. At the same time an average return on assets was $3.1 \%$ as average return on equity made up $6.2 \%$. A total return on investment gave an average of $3.6 \%$ in 2011-2015. It should be mentioned that the decrease in margins and returns was reflected in firms' capitalization and enterprise value reduction in 2011-2014, while an improvement in earnings and profitability led to a jump in stock prices in 2015.

In 2011-2015, a significant decrease in debt ratios was noticed in companies from WIG-FOOD index (table 4). The total debt to equity ratio has decreased from $83.8 \%$ in 2011 to $47.7 \%$ in 2015 as the average ratio came to $63.2 \%$. Generally, such a situation implied the drop in leverage and signalled a relatively lower profitability of equity capital. The same trend arose in the relation of debt to assets and debt to sales ratio that decreased to $26.1 \%$ and $21.4 \%$ accordingly. The total debt to enterprise value ratio demonstrated less volatility dropping from $37.7 \%$ in 2011 to $31.6 \%$ in 2015. Comparing the decrease of debt share and simultaneous rise of the enterprise value, it could be concluded that high debt level negatively influenced the market capitalization. This gave an evidence of an importance of capital structure decisions for investors. Considering a trade-off theory managers of companies from WIG-FOOD index had to pay more attention to possible bankruptcy costs than to tax benefits arising from higher leverage and accept more conservative strategies of financing (Wasilewski M., Zabolotnyy S., 2009). Moreover, risk aversion in agribusiness could result in preference to internal sources of financing in line with pecking-order 
theory. However, to fully understand the volatility of market capitalization, some external factors such as global investors' sentiment, phase of business cycle and momentum should be carefully studied.

Capital structure of companies from WIG-FOOD index

\begin{tabular}{|c|c|c|c|c|}
\hline \multirow{2}{*}{ Period } & \multicolumn{4}{|c|}{ Ratio ( \%) } \\
\cline { 2 - 5 } & Total debt/Sales & Total Debt/Assets & Total Debt/Equity & Total Debt/EV \\
\hline FY 2011 & 34.3 & 36.3 & 83.8 & 37.7 \\
\hline FY 2012 & 34.4 & 36.8 & 83.9 & 41.4 \\
\hline FY 2013 & 25.2 & 26.5 & 49.0 & 32.3 \\
\hline FY 2014 & 25.6 & 30.1 & 59.6 & 39.4 \\
\hline FY 2015 & 21.4 & 26.1 & 47.7 & 31.6 \\
\hline $\begin{array}{c}\text { Weighted } \\
\text { average }\end{array}$ & $\mathbf{2 8 . 1}$ & $\mathbf{3 1 . 2}$ & $\mathbf{6 3 . 2}$ & $\mathbf{3 6 . 5}$ \\
\hline
\end{tabular}

Source: authors' calculations

Pearson correlation coefficients between the enterprise value, profitability

Table 5 and debt ratios of companies from WIG-FOOD index

\begin{tabular}{|c|c|c|c|c|c|c|c|c|c|c|}
\hline VARIABLE & $\begin{array}{c}\text { Market } \\
\text { Cap }\end{array}$ & EV & $\begin{array}{l}\text { Return } \\
\text { on } \\
\text { Equity }\end{array}$ & $\begin{array}{l}\text { Return } \\
\text { on } \\
\text { Assets }\end{array}$ & $\begin{array}{l}\text { EBIT / } \\
\text { Sales }\end{array}$ & $\begin{array}{c}\text { Net } \\
\text { income/ } \\
\text { Sales }\end{array}$ & $\begin{array}{l}\text { Debt/ } \\
\text { Equity }\end{array}$ & $\begin{array}{l}\text { Debt/ } \\
\text { Assets }\end{array}$ & $\begin{array}{l}\text { Price/ } \\
\text { Share }\end{array}$ & $\begin{array}{c}\text { Price/ } \\
\text { Book }\end{array}$ \\
\hline \multirow{2}{*}{ Market Cap } & 1 & 0.9872 & 0.3707 & 0.3039 & 0.1932 & 0.1705 & 0.0351 & 0.1951 & 0.4928 & 0.3419 \\
\hline & $p=---$ & $p=0.00$ & $p=.001$ & $p=.008$ & $p=.097$ & $p=.144$ & $p=.765$ & $p=.094$ & $p=.000$ & $p=.003$ \\
\hline \multirow{2}{*}{ EV } & 0.9872 & 1 & 0.3329 & 0.2566 & 0.1928 & 0.1472 & 0.1001 & 0.2712 & 0.4707 & 0.2887 \\
\hline & $p=0.00$ & $p=---$ & $p=.004$ & $p=.026$ & $p=.097$ & $p=.208$ & $p=.393$ & $p=.019$ & $p=.000$ & $p=.012$ \\
\hline \multirow{2}{*}{$\begin{array}{l}\text { Return on } \\
\text { Equity }\end{array}$} & 0.3707 & 0.3329 & 1 & 0.946 & 0.7444 & 0.8406 & -0.1057 & -0.0647 & 0.679 & 0.5437 \\
\hline & $p=.001$ & $p=.004$ & $p=---$ & $p=0.00$ & $p=.000$ & $p=0.00$ & $p=.367$ & $p=.581$ & $p=.000$ & $p=.000$ \\
\hline \multirow{2}{*}{$\begin{array}{l}\text { Return on } \\
\text { Assets }\end{array}$} & 0.3039 & 0.2566 & 0.946 & 1 & 0.7874 & 0.9217 & -0.2985 & -0.2526 & 0.7214 & 0.4929 \\
\hline & $p=.008$ & $p=.026$ & $p=0.000$ & $p=---$ & $p=.000$ & $p=0.00$ & $p=.009$ & $p=.029$ & $p=.000$ & $p=.000$ \\
\hline \multirow{2}{*}{ EBIT/Sales } & 0.1932 & 0.1928 & 0.7444 & 0.7874 & 1 & 0.9115 & -0.1237 & -0.037 & 0.5592 & 0.3187 \\
\hline & $p=.097$ & $p=.097$ & $p=.000$ & $p=.000$ & $p=---$ & $p=0.00$ & $p=.290$ & $p=.753$ & $p=.000$ & $p=.005$ \\
\hline \multirow{2}{*}{$\begin{array}{l}\text { Net } \\
\text { income/ } \\
\text { sales }\end{array}$} & 0.1705 & 0.1472 & 0.8406 & 0.9217 & 0.9115 & 1 & -0.2758 & -0.2227 & 0.6385 & 0.3917 \\
\hline & $p=.144$ & $p=.208$ & $p=0.00$ & $p=0.00$ & $p=0.00$ & $p=---$ & $p=.017$ & $p=.055$ & $p=.000$ & $p=.001$ \\
\hline \multirow{2}{*}{$\begin{array}{l}\text { Debt/ } \\
\text { Equity }\end{array}$} & 0.0351 & 0.1001 & -0.1057 & -0.2985 & -0.1237 & -0.2758 & 1 & 0.9067 & $0.0716^{-}$ & 0.0109 \\
\hline & $p=.765$ & $p=.393$ & $p=.367$ & $p=.009$ & $p=.290$ & $p=.017$ & $p=---$ & $p=0.00$ & $p=.542$ & $p=.926$ \\
\hline \multirow{2}{*}{$\begin{array}{l}\text { Debt/ } \\
\text { Assets }\end{array}$} & 0.1951 & 0.2712 & -0.0647 & -0.2526 & -0.037 & -0.2227 & 0.9067 & 1 & 0.0006 & 0.0059 \\
\hline & $p=.094$ & $p=.019$ & $p=.581$ & $p=.029$ & $p=.753$ & $p=.055$ & $p=0.00$ & $p=---$ & $p=.996$ & $p=.960$ \\
\hline \multirow{2}{*}{$\begin{array}{l}\text { Price/ } \\
\text { Share }\end{array}$} & 0.4928 & 0.4707 & 0.679 & 0.7214 & 0.5592 & 0.6385 & -0.0716 & 0.0006 & 1 & 0.4907 \\
\hline & $p=.000$ & $p=.000$ & $p=.000$ & $p=.000$ & $p=.000$ & $p=.000$ & $p=.542$ & $p=.996$ & $p=---$ & $p=.000$ \\
\hline \multirow{2}{*}{$\begin{array}{l}\text { Price/ } \\
\text { Book }\end{array}$} & 0.3419 & 0.2887 & 0.5437 & 0.4929 & 0.3187 & 0.3917 & 0.0109 & 0.0059 & 0.4907 & 1 \\
\hline & $p=.003$ & $p=.012$ & $p=.000$ & $p=.000$ & $p=.005$ & $p=.001$ & $p=.926$ & $p=.960$ & $p=.000$ & $p=---$ \\
\hline
\end{tabular}

Source: authors' calculations

Pearson correlation coefficients indicate a strong positive relation between the market capitalization and enterprise value of companies from WIG-FOOD Index (Table 5). Moderate positive relations were demonstrated between the market capitalization (and enterprise value) and 
profitability ratios of companies from WIG-FOOD Index. This implied that an increase in profitability ratios contributed to a growth in the market capitalization and enterprise value. Value variables didn't show statistically significant linear correlations with debt ratios of firms. Only enterprise value was moderately correlated with debt to asset ratio $(0.2712)$ that meant the increase of debt in assets could lead to a rise in enterprise value. This could be true in certain situations as according to the general formula of enterprise value total debt adds to the firm's value. However, as it was mentioned above, a growth of debt didn't automatically translate into higher market capitalization due to rising bankruptcy costs and investors' uncertainty. At the same time statistically significant negative correlations between the profitability and debt ratios gave a strong evidence of a trade-off. An increase in debt level of companies was connected to the fall of profitability. From one hand, the reason for this could be the scarcity of internal sources of financing in companies with lower earnings that led to a further increase of total debt share. From another hand, insufficient earnings and internal funds could produce the necessity of additional borrowing to meet the liquidity requirements. These arguments justified drops in market capitalization of highly leveraged companies. Considering earlier research outcomes this gave an evidence of relatively higher efficiency of conservative strategies of financing in terms of enterprise value and profitability. To sum up, stronger positive relations between market capitalization and profitability should incline managers to reduce debt that would probably result in higher financial efficiency and market capitalization as well as enterprise value of companies in agribusiness sector.

\section{Conclusions}

The article presents relations between the enterprise value, efficiency and capital structure of Polish joint-stock companies from food sector listed on the Warsaw Stock Exchange. Considering the results of research, the following conclusions have been formulated.

1) In spite of robust growth of Polish economy, companies from WIG-FOOD index didn't demonstrate a significant increase in the market capitalization and enterprise value in 20112015. The main reason for this was a weakening demand for food products influencing firms' earnings and margins as well as a number of external factors associated with specific risks of the Central European emerging market ${ }^{1}$.

2) Generally, the enterprise value of companies from WIG-FOOD sector was primarily subject to the market capitalization and debt fluctuations. It was noticed that a simultaneous drop of the debt level and an increase in cash resulted in a higher market capitalization due to fading bankruptcy risk. This gave a strong evidence of an importance of capital structure for managers and investors who preferred more conservative strategies of financing.

3) Companies from WIG-FOOD index were financially efficient but demonstrated volatility of margins and returns for investors in 2011-2015. An increase in earnings and profitability ratios had a positive impact on the market capitalization and enterprise value that was in line with theoretical assumption of value maximization principle.

4) In 2011-2015, debt ratios of WIG-FOOD index has decreased that implied a higher liquidity and financial strength of companies. A slump in debt ratios led to a rise of the market capitalization and enterprise value. Hence companies with higher share of equity would be more preferable targets for investors. 
5) There was an evidence of a trade-off between the profitability and debt level of WIG-FOOD companies. The market capitalization and enterprise value had statistically significant positive correlations with profitability of companies while correlation coefficients between debt and profitability ratios were negative. Considering the influence of debt level on the market capitalization it could be expected that managers would strive for reducing external sources of financing and increasing operating efficiency to maximize the value of their companies for shareholders.

\section{Bibliography}

1. Bartkiewicz P., Lecki M. (2015). GPW w Warszawie - rownia pochyla, Zeszyty Naukowe Uniwersytetu Szczecińskiego, nr 855, Finanse, Rynki Finansowe, Ubezpieczenia, nr 74, t. 1, Szczecin, pp. 11-22.

2. Berk J., DeMarzo P. (2017). Corporate Finance. Fourth Edition, Pearson, Harlow, p.1167.

3. Damodaran A. (1999). Value Creation and Enhancement: Back to the Future, pp. 2-15. http://www.stern.nyu.edu/fin/workpapers/papers99/wpa99018.pdf. Access: 15.02.2018.

4. European Commission (2017). Country Report Poland 2017. Commission Staff Working Document, Brussels, p.47.

5. Franc-Dabrowska J., Madra-Sawicka M., Bereznicka J. (2017). Is There a Cost of an Agricultural Business Owner's Capital? : philosophical interpretation of cost of equity capital in agriculture, 7th Global Innovation and Knowledge Academy (GIKA) : conference proceedings : Innovation, knowledge, judgment, and decision-making as virtuous cycles, Lisbon, June 28-30, 2017, pp. 1-19.

6. Frank M.Z., Goyal V.K. (2003). Testing the Pecking Order Theory of Capital Structure, Journal of Financial Economics, 67, pp. 217-248.

7. Kahan D. (2008). Managing Risk in Farming, Food and Agriculture Organization of the United Nations, Rome, pp. 2-10.

8. Ministry of Agriculture and Rural Development of Poland (2015). Agriculture and Food Economy in Poland, Warsaw, p. 156.

9. Modigliani F., Miller M.H. (1958): The Cost of Capital, Corporation Finance and The Theory of Investment, The American Economic Review, Vol. 48, No. 3, pp. 261-297.

10. Myers S. C. (2001). Capital Structure. The Journal of Economic Perspectives, Vol.15, No. 2 (Spring 2001), pp.81-102.

11. Panfil M. (2009). Wycena biznesu w praktyce, Poltext, Warszawa, pp. 17-22.

12. Stanisz A. (2007). Przystepny kurs statystyki, Tom 1. Statsoft, Krakow, pp. 289-300.

13. Higgins R. (2012). Analysis for Financial Management, Mc-Graw Hill Irwin,Tenth Edition, New York, p. 480.

14. Wasilewski M., Zabolotnyy S. (2009). Strategies and Effectiveness of Working Capital Management in Food Industry Enterprises, 10th International Scientific Conference on Economic Science for Rural

Development Location: Jelgava, Latvia, pp. 111-117. 